\title{
Tokat Çevresinde Yayılış Gösteren Bazı Tıbbi ve Yenilebilir Bitkilerin Etnobotanik Özelliklerinin Belirlenmesi Üzerine Bir Araştırma
}

\author{
${ }^{*}$ Sibel Ulcay, ${ }^{2}$ Gülcan Şenel \\ ${ }^{1}$ Ahi Evran Üniversitesi, Ziraat Fakültesi, Tarla Bitkileri Bölümü, Tıbbi ve Aromatik Bitkiler Anabilim Dalı, Kırşehir, Türkiye, \\ sibelulcay@gmail.com iD \\ ${ }^{2}$ Ondokuz Mayıs Üniversitesi, Fen Edebiyat Fakültesi, Bivoloji Bölümü, Samsun, Türkiye, \\ gsenel@ omu.edu.tr iD
}

Araştırma Makalesi

Geliş Tarihi: 19.11.2018

Kabul Tarihi: 09.04.2019

$\ddot{O} \mathbf{z}$

$\mathrm{Bu}$ çalışma, Tokat çevresinde yayılış gösteren ve ekonomik bakımdan önem arz eden bazı bitkilerin, etnobotanik özelliklerinin belirlenmesi amaciyla yürütülmüştür. Bu amaçla Erodium cicutarium L. LÂ'HERIT. (Geraniaceae), Fumaria officinalis L. (Papaveraceae), Scandix pecten-veneris L. (Apiaceae), Stellaria media L. VILL. subsp. media L. VILL (Caryophyllaceae), Plantago lanceolata L. (Plantaginaceae), Rumex acetosella L. (Polygonaceae), Tragopogon pratensis subsp. pratensis L. (Asteraceae) olmak üzere toplam 7 takson incelenmiştir. Türler çiçekli dönemlerinde toplanmış, herbaryum örneği haline getirilmiştir. Yapılandırılmış ve yarı yapılandırılmış görüşme yöntemi kullanılarak yöre halkından bilgiler edinilmiştir. Bu amaçla 297 yöre insanı ile görüşülmüş ve katılımcıların özellikleri belirlenmiştir. Ayrıca, bitkilerin kullanım değerleri (UV) de hesaplanmıştır. Bitkilerin tümü, pişirilerek besin olarak tüketilmektedir. Geleneksel tedavide en fazla kullanılan Stellaria media subsp. media'dır. Bu bitkilerin hemoroid ve mide kanamalarında faydalı olduğu yöre halkı tarafından ifade edilmiştir. Ayrıca Scandix pecten veneris ve Plantago lanceolata' nın ağrı kesici, Rumex acetosella'nın kan şekerini düzenleyici, Erodium cicutarium sindirim sistemi organlarındaki yaraları iyileştirici, Tragopogon pratensis subsp. pratensis in sindirim sistemini düzenleyici, Fumaria officinalis 'in idrar söktürücü olarak geleneksel tedavide kullanıldığı ifade edilmektedir. Ayrıca bahsedilen türlerden çiçeklendikten sonra, hayvan yemi olarak da faydalanılmaktadır.

Anahtar Kelimeler: T1bbi Bitkiler, Yenilebilir Bitki, Etnobotanik, Tokat

\section{An Ethnobotanical Study on Some Medicinal and Edible Plants Distributed Around Tokat in Turkey}

\author{
${ }^{* 1}$ Sibel Ulcay, ${ }^{2}$ Gülcan Şenel \\ ${ }^{1}$ Ahi Evran University, Faculty og Agriculture, Department of Field Crops, Kırşehir, Turkiye \\ ${ }^{2}$ Ondokuz Mayis University, Faculty of Science and Letters, Biology, Samsun, Turkiye
}

\begin{abstract}
In this study, it is aimed to determine the local characteristics of some economically valuable plants distributed around Tokat. Erodium cicutarium (L.) LÂ'HERIT. (Geraniaceae), Fumaria officinalis L. (Papaveraceae), Scandix pecten-veneris L. (Apiaceae), Stellaria media (L.) VILL. subsp. media (L.) VILL (Caryophyllaceae), Plantago lanceolata L. (Plantaginaceae), Rumex acetosella L. (Polygonaceae), Tragopogon pratensis subsp. pratensis L. (Asteraceae) were examined 7 taxa. Species were collected in flowering periods and transformed into herbarium specimens. Information was obtained from local people by using structured and semi-structured interview method. In addition, for this purpose, interviews were conducted with 297 local people between them and their demographic characteristics were determined. Usage values of plants (UV) were also calculated. All plants are consumed as food by cooking. Among the plants forming the research topic, the most commonly used Stellaria media subsp. media in traditional therapy. It is indicated by the local people that it is useful in hemorrhoids and stomach bleeding. It is stated that Scandix pecten veneris and Plantago lanceolata used as an analgesic, Rumex acetosella used as a blood glucose regulator, Erodium cicutarium used in ulcer treatment, Tragopogon pratensis subsp. pratensis used as a digestive system regulator and Fumaria officinalis used as a diuretic in traditional therapy. All species are used as animal feed after flowering.
\end{abstract}

Keywords: Medicinal plants, Edible Plant, Ethnobotany, Tokat

*Sorumlu Yazar: Ahi Evran Üniversitesi, Ziraat Fakültesi, Tarla Bitkileri Bölümü, Tıbbi ve Aromatik Bitkiler Anabilim Dalı, Kırşehir, Türkiye, sibelulcay@gmail.com 


\section{GİRIŞ}

Ülkemiz coğrafik konumu, iklim, toprak ve jeomorfolojik özellikleri sayesinde oldukça zengin bir floristik yapıya sahiptir. 1950'li y1llarda Türkiye'de teşhis edilen 2480 bitki türüne karş1lık [1,2] günümüzde bu sayı 11.707'e ulaşmıştır. Türkiye, yok olma tehlikesi bulunan birçok türe ve dar yayılışlı endemik türlere ev sahipliği yapmaktadır. Teşhis edilen endemik bitki türü sayısı 3649'dur [3]. Ayrıca ülkemiz birçok bitki türünün anavatanı ve kültüre alınma merkezidir [4]. Tokat ili de, iklim ve coğrafik özellikleri nedeniyle zengin bir bitki örtüsüne sahiptir. Bununla birlikte Türk Etnobotanik Veri Tabanında etnobotanik açıdan iyi tanınan 12 il arasında yer almaktadır. Bu iller Sivas, Erzurum, İstanbul, Gaziantep, Balıkesir, Konya, Sinop, İçel, Afyonkarahisar, Bursa, Diyarbakır ve Tokat'tır. Ayrıca tıbbi bitki yoğunluğu açısından da dikkat çekmektedir [5].

Tarih boyunca insanoğlu yararlı gördüğü bitkileri tanıma yoluna gitmiş, tanıtmış ve özellikle de hastalıkların tedavisinde kullanmıştır [6,7,8]. Bitkilerden faydalanma yolları değişik kültürlere göre farklı olsa da; genellikle bitkiler gıda, tedavi edici, yapı malzemesi, yakıt, hayvan yemi, boyar madde, süs eşyası yapımı ve inançsal amaçlar için kullanılmışlardır [9,10,11]. Faydalanma yolları, zaman içerisinde oluşan bazı değişiklikler ve gelişmelerle birlikte nesilden nesile aktarılarak günümüze kadar gelmiştir [7,8,9]. $\mathrm{Bu}$ bitkilerin kullanım alanlarının ve yöresel isimlerinin bilinmesi insanlık mirasının gelecek nesillere ulaştırılması açısından oldukça önemlidir [12]. Türkiye'de değişik alanlarda etnobotanik çalışmalar Baytop [9], Sezik ve ark. [13,14], Ertuğ [15] Tuzlacı ve Aymaz [16], Özgökçe ve Özçelik [17], Güneş ve Özhatay [18], Polat ve Satıl [19], Korkmaz [20], Kocabaş ve ark. [21], Yeşilyurt ve ark. [22], Bulut ve ark. [23] tarafindan geçmişten günümüze yapılmıştır. Bu araştırma ile Tokat ili merkez ilçesi ve çevresinde, tıbbi ve yenilebilir bitki türlerinin halk arasında nasıl kullanıldığının tespit edilmesi ve türlerin bazı etnobotanik özelliklerinin belirlenmesi amaçlanmıştır.

\section{MALZEME VE YÖNTEM}

\subsection{Malzeme}

$\mathrm{Bu}$ çalışmada Erodium cicutarium (L.) LÂ'HERIT. (Geraniaceae), Fumaria officinalis L. (Papaveraceae), Scandix pecten-veneris L. (Apiaceae), Stellaria media (L.) VILL. subsp. media (L.) VILL (Caryophyllaceae), Plantago lanceolata L. (Plantaginaceae), Rumex acetosella L. (Polygonaceae), Tragopogon pratensis subsp. pratensis L. (Asteraceae) taksonları incelenmiştir. Araştırmada kullanılan türlere ait örnekler, 2017 yılında, bitkilerin çiçekli oldukları dönem olan Nisan ve Eylül ayları arasında Tokat'taki değişik yerlerden toplanmıştır. Bitki örneklerinin teşhisleri Flora of Turkey'e göre [24,25,26,27,28,29,30,31] yapılmıştır. Toplanan materyallerin bir kısmı herbaryum örneği haline getirilmiştir (Tablo 1)

\subsubsection{Araştırma Alanı}

Tokat, Deveci dağlarının orta kesiminin kuzey yamaçlarından doğarak soldan Yeşilırmak'a kavuşan bir akarsu vadisinin yamaçlarında kurulmuştur. Kent, çok engebeli bir bölgede Orta Karadeniz kıyılarını ve İç ve Doğu Anadolu'ya bağlayan önemli yolların kavşağında eski bir yerleşim yeridir (Şekil 1).

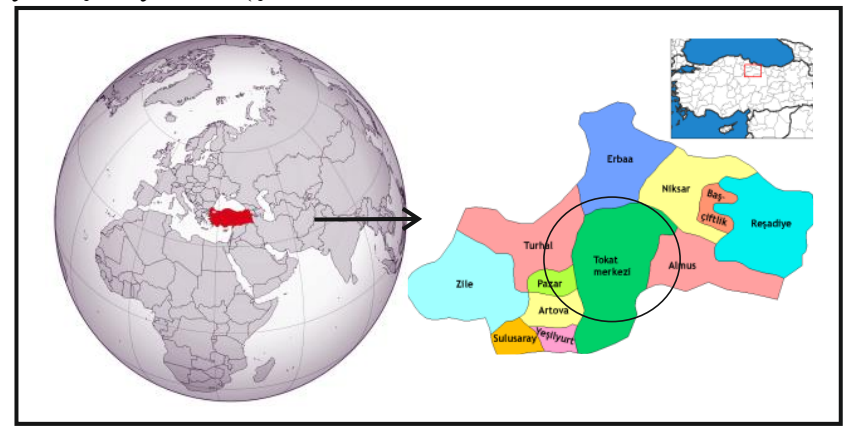

Şekil 1. Araştırma alanı

Tokat, kuzeyinde Samsun, kuzeydoğusunda Ordu, güneyinde Sivas, güneybatısında Yozgat, batısında: Amasya ili ile çevrilidir. İlin toplam yüzölçümü $10.071 \mathrm{~km}^{2}$ 'dir. Kapladığı alan açısından Türkiye topraklarının \% 1.3'ünü kapsar. Denizden yükseltisi 623 metredir. Coğrafi koordinatları, $39^{\circ} 51^{\prime}-40^{\circ} 55^{\prime}$ Kuzey enlemleri ile $35^{\circ} 27^{\prime}$ $37^{\circ} 39^{\prime}$ Doğu boylamlarıdır.

Araştırma alanını, Tokat-Merkez ve bağlı köyleri ile ilin batısında bulunan Pazar ilçesi ve bağlı köyleri oluşturmaktadır.

\subsection{Yöntem}

Çalışmamızda yapılandırılmış ve yarı yapılandırılmış görüşme yöntemi kullanılmıştır [32] Ayrıca il merkezinde kurulan pazarda, köyden gelen satıcılarla ve il merkezindeki bazı kişilerle görüşmeler yapılmıştır. Araştırmaya 297 kişi katılmıştır. $\mathrm{Bu}$ görüşmeler esnasında katılımcıların demografik özellikleri, tespit edilmiştir. Ayrıca türlerin yöresel isimleri, kullanım amacı ve metodu, kullanılan kısımları ile kullanım değerleri (UV) ortaya konulmuştur [33].

\subsubsection{Sonuçların Değerlendirilmesi}

Verilerin IBM SPSS V23 ile analizleri yapılmıştır. Taksonların halk arasında kullanım sayılarının normal dağılıma uygunluğu Shapiro Wilk testi ile incelenmiştir. Cinsiyete göre bitkisel kullanım sayıları parametrik olamayan yöntemlerden Mann Whitney U testi [34]. ile incelenmiştir. Nitel verilerin karşılaştırılmasında Ki Kare testi ile, çoklu oran karşılaştırmaları Marascuillo prosedürü ile incelenmiştir. Nicel veriler ortanca (min-mak), nitel 
Tablo 1. Taksonlar hakkında genel bilgiler ve herbaryum örneklerinin toplandığı yerler

\begin{tabular}{|c|c|c|c|c|c|c|}
\hline Takson & Ömür & $\begin{array}{l}\text { Çiçeklenme } \\
\text { (ay) }\end{array}$ & $\begin{array}{l}\text { Yükseklik } \\
\text { (m) }\end{array}$ & Lokalite & Element & $\begin{array}{l}\text { Herbaryum } \\
\text { No }\end{array}$ \\
\hline E. cicutarium & Tek y1llık & $3-5$ & $558 \mathrm{~m}$ & $\begin{array}{l}\text { Tatar Köyü (Pazar), } \\
\text { Tokat Merkezi }\end{array}$ & Akdeniz & $150 S$ \\
\hline F. officinalis & Tek y1llık & $4-5$ & $554 \mathrm{~m}$ & $\begin{array}{l}\text { Menteşe Köyü (Pazar), } \\
\text { Tokat-Geyras (Merkez) }\end{array}$ & $\begin{array}{l}\text { Avrupa- } \\
\text { Sibirya }\end{array}$ & $178 S$ \\
\hline P. lanceolata & Çok yıllık & $4-10$ & $488 \mathrm{~m}$ & $\begin{array}{l}\text { Tokat-Merkez, } \\
\text { Taşlıçiftlik Mevkii }\end{array}$ & $\begin{array}{l}\text { Avrupa- } \\
\text { Sibirya }\end{array}$ & $229 \mathrm{~S}$ \\
\hline R. acetosella & Çok yıllık & $5-8$ & 544 & $\begin{array}{l}\text { Çiftlik Köyü (Pazar- } \\
\text { Tokat) }\end{array}$ & Kozmopolit & $275 \mathrm{~S}$ \\
\hline S. pecten veneris & Tek y1llık & $3-6$ & $488 \mathrm{~m}$ & $\begin{array}{l}\text { Tokat-Merkez, } \\
\text { Taşlıçiftlik Mevkii }\end{array}$ & $\begin{array}{l}\text { Avrupa- } \\
\text { Sibirya }\end{array}$ & $125 \mathrm{~S}$ \\
\hline $\begin{array}{l}\text { S. media subsp. } \\
\text { media }\end{array}$ & Tek y1llık & $4-6$ & $574 \mathrm{~m}$ & $\begin{array}{l}\text { Pazar (Merkez), Tokat- } \\
\text { Merkez }\end{array}$ & $\begin{array}{l}\text { Avrupa- } \\
\text { Sibirya }\end{array}$ & $200 \mathrm{~S}$ \\
\hline $\begin{array}{l}\text { T. pratensis subsp } \\
\text { pratensis }\end{array}$ & $\begin{array}{l}\text { Tek, iki, } \\
\text { çok yıllık }\end{array}$ & $5-7$ & $544 \mathrm{~m}$ & $\begin{array}{l}\text { Çiftlik Köyü (Pazar- } \\
\text { Tokat) }\end{array}$ & $\begin{array}{l}\text { Avrupa- } \\
\text { Sibirya }\end{array}$ & $225 \mathrm{~S}$ \\
\hline
\end{tabular}

veriler ise frekans (yüzde) şeklinde sunulmuştur. Anlamlılık düzeyi $\mathrm{p}<0.05$ olarak alınmıştır. Morfolojik ve anatomik ölçümlerde standart sapma, ortalama, minimum ve maksimum değerler IBM SPSS V23 programı ile hesaplanmıştır [35].

Bitkilerin kullanım s1klık (Informant consensus factor ICF veya FIC ) değerleri [33] hesaplanmıștır. FIC = Nur $\mathrm{Nt} / \mathrm{Nur}-1$ ile formüle edilmektedir. (Nur: Her bir tür için atıfta bulunma sayısı, Nt: Belirlenen toplam bitki sayısıdır. $\mathrm{Bu}$ metot bilgilerin homojenitesini kontrol etmektedir. FIC değeri yüksek çıkarsa (1'e yakın) topluluk için kriterler iyi seçilmiş veya bilgilendiriciler gerekli bilgiyi almış anlamına gelmektedir [36,37,38,39]. Belirli bir hastalığın tedavisinde etkili olduğu düşünülen tıbbi bitkiler daha yüksek FIC değerine sahiptir [22, 40]. Literatürde FIC veya ICF olarak katılmış olan Bilgi Veren Kişiler Arasında Fikir Birliği Faktörü Trotter and Logan tarafindan UV olarak kısaltılmıştır. UV değeri de bölgede iyi bilinen türler arasındaki bağıntıyı göstermektedir. UV= U/N ile formüle edilmektedir. UV: Başvurulan türlerin kullanım değeri, U: Tür başına düşen atıf sayısı, N: Bilgilendirici sayısı [33].

\section{BULGULAR}

Çalışmamız 297 kişi ile gerçekleştirilmiştir. Katılımcıların demografik özellikleri tespit edilmiştir. Buna araştırmaya katılan bireylerde erkeklerin oranı \%26.3 iken kadınların oranı \%73.7'dir. Katılımcıların \%82.4'ü evli ve \%43.1'i ilkokul mezunudur (Şekil 2).

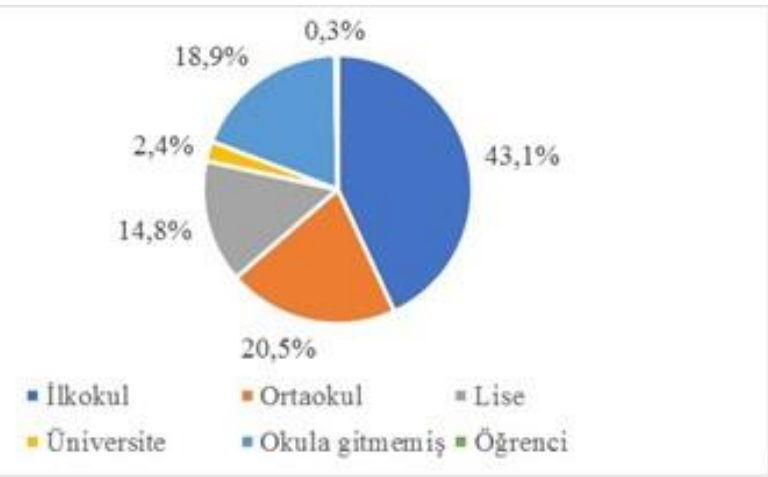

Şekil 2. Katılımcıların eğitim durumları

Köyde yaşayanların oranı \%63.9 iken şehirde yaşayanların oranı \%33.7'dir (Şekil 3). Ev hanımı olanların oranı \%60,6 iken katılımcıların \%21.2'si çiftçidir (Şekil 3).

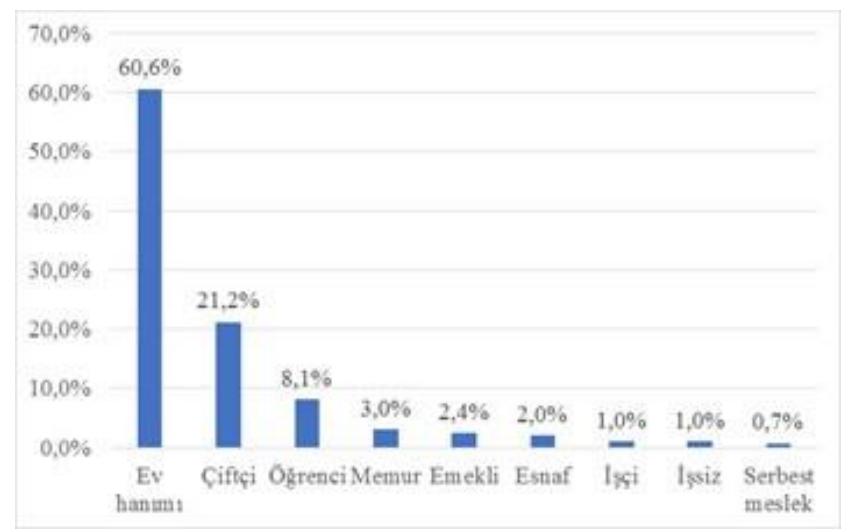

Şekil 3. Katılımcıların meslekleri

Katılımcıların yaşları ise daha çok 35-45'tir (Şekil 4). 


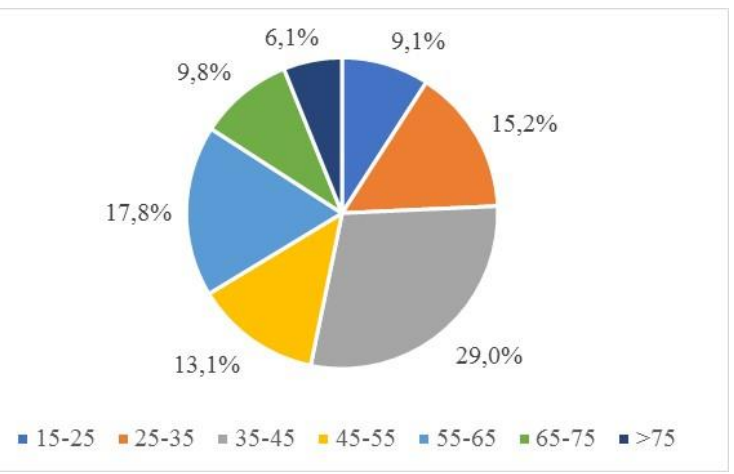

Şekil 4. Katılımcıların yaş aralıkları

"Bitkileri kullaniyor musunuz?" sorusuna evet diyenlerin oran1 \%65.2 iken k1smen diyenlerin oranı \%31.1 ve hayır diyenlerin oranı da \%3.7'dir. Bitkileri temin etme yolu olarak doğadan kendisi toplayanların oranı \%53.5 iken doğadan ve sadece satın alma yolu ile temin edenlerin oranı $\% 34$ ve satın aliyorum diyenlerin oranı da \%12.5'tir. Bitkileri çarşıdan (pazar, aktar vb.) satın alanların oranı \%34.4 marketten satın alanların oranı \%5.3 market ve çarşıdan satın alanların oranı \%29 yetiştiriciden satın alanların oranı $\% 22.1$ ve yetiştirici ile marketten satın alanların oranı da $\% 9.2$ 'dir

Katılımcıların \%88.9'u söz konusu bitkilerden tıbbi amaçlı faydalandıklarını belirtirken, \%69'u yiyecek, \%13.5'i hayvan yemi, \%1'i tat ve aroma, $\% 0.3$ 'ü süs ve $\% 0.3$ 'ü de inanışsal olarak yararlandıklarını belirtmişlerdir (Şekil 5). Bilgi kaynağı olarak yaşlı insanlardan bilgi aldığını belirtenlerin oranı \%89.1 iken kitle iletişim araçlarından faydalananların oranı $\% 45.6$ ve arkadaşlarından bilgi alanların oranı da \%3.7'dir. (Birden fazla cevap alındığ 1 için toplamlar \%100'den fazladır).

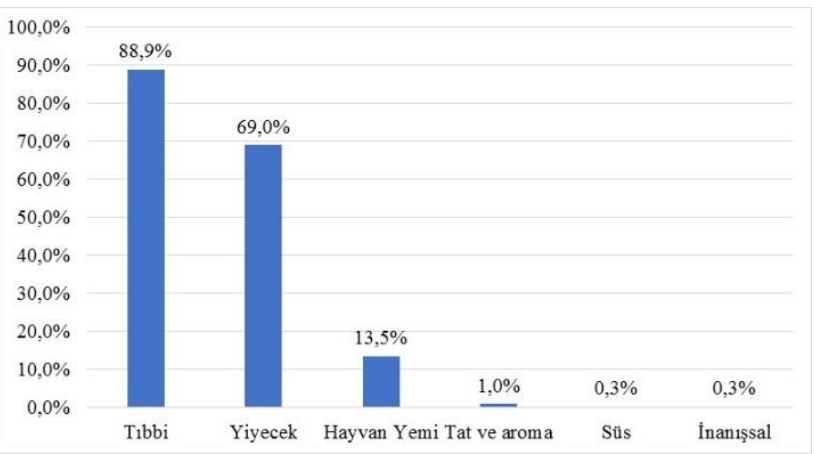

Şekil 5. Katılımcıların bitkileri kullanım amaçları

Söz konusu bitkilerinden Erodium cicutarium'un yöre halkı tarafından kullanım oranı \%17.5 iken, Fumaria officinalis kullanım oranı \%22.2, Plantago lanceolata kullanım oranı \%18.9, Rumex acetosella \%44.7, Scandix pecten-veneris \%13.5, Stellaria media subsp. media $\% 64.6$ ve Tragopogon pratensis subsp. pratensis kullanım oranı da \%62.6 olarak elde edilmiştir (Şekil 6). Erodium cicutarium, Fumaria officinalis, Plantago lanceolata ve Scandix pecten-veneris kullanım oranları arasında fark yoktur ve en düşük kullanım oranı bu bitkilerde tespit edilmiştir. Rumex acetosella kullanım oranı da diğer tüm bitkileri kullanım oranlarından farklıdır ve orta düzey bir kullanıma sahiptir. En yüksek kullanım oranı ise Stellaria media subsp. media ve Tragopogon pratensis subsp. pratensis'e aittir.

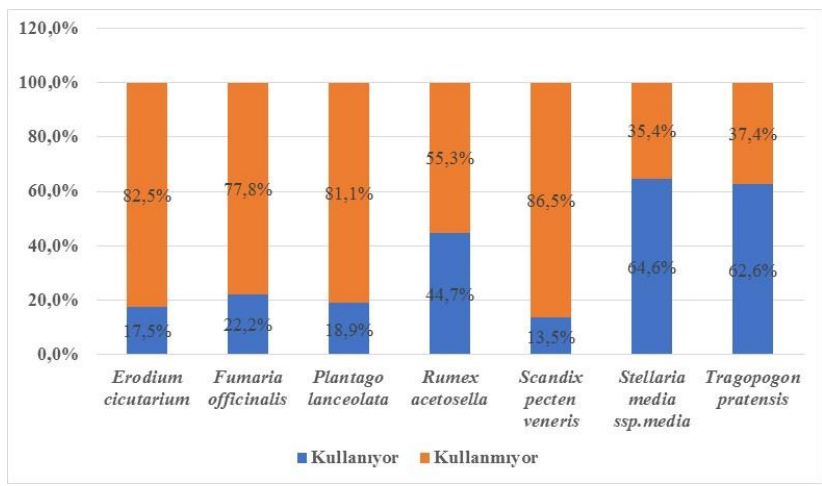

Şekil 6. Yöre halkının bitkileri kullanma oranları

Bitkileri kullanım oranların cinsiyetlere göre incelendiğinde Erodium cicutarium kullanım oranı erkeklerde \%7.7 iken kadınlarda \%21 olarak elde edilmiştir ve bu oranlar cinsiyete göre farkl1lık göstermektedir ( $\mathrm{p}=0.008 \mathrm{p}$ : istatistiksel anlamlılığı ifade eden hata miktarını gösterir.). Fumaria officinalis kullanım oranı cinsiyete bağlı değildir $(\mathrm{p}=0.459)$. Erkeklerde kullanım oranı \%19.2 iken kadınlarda \%23.3 olarak elde edilmiştir. Plantago lanceolata kullanım oranı cinsiyete bağlı değildir $(\mathrm{p}=0.565)$. Erkeklerde kullanım oranı $\% 16.7$ iken kadınlarda \%19.6 olarak elde edilmiştir. Rumex acetosella kullanım oranı cinsiyete bağlı değildir $(\mathrm{p}=0.133)$. Erkeklerde kullanım oranı \%37.2 iken kadınlarda \%47 olarak elde edilmiştir. Scandix pectenveneris kullanım oranı cinsiyete bağlı değildir $(\mathrm{p}=0.335)$. Erkeklerde kullanım oranı \%16.7 iken kadınlarda \%12.3 olarak elde edilmiştir. Stellaria media subsp. media kullanım oranı cinsiyete bağlı değildir $(\mathrm{p}=0.135)$. Erkeklerde kullanım oranı \%57.7 iken kadınlarda \%67.1 olarak elde edilmiştir. Tragopogon. pratensis subsp. pratensis kullanım oranı cinsiyete bağlı değildir $(\mathrm{p}=0.062)$. Erkeklerde kullanım oranı \%53.8 iken kadınlarda \%65.8 olarak elde edilmiştir. Bitki adedi 7 olarak dikkate alındığında erkeklerin bu bitkilerden ortanca olarak üçünü kadınların ise dördünü kullandığı tespit edilmiştir. Erkek ve kadınların kullandıkları bitkilerin sayıları arasında fark yoktur ( $\mathrm{p}=0.107)$. Eğitim seviyeleri ile bitkilerin kullanım oranları arasında bir ilişki bulunmamıştır ( $\mathrm{p}>0.05)$.

Erodium cicutarium yöre halkı tarafindan "tikencik, dikencik" olarak bilinmektedir. Mayıs ayından önce çiçeklenmeden yaprak ve dallar toplanır. "Pancar kavurması" adı verilen birden fazla bitkinin konulduğu yemekte kullanılır. Ayrıca yaprakları zeytinyağı ile pişirilip haftada bir iki kez yenilirse sindirim sistemini düzenlediği, mideyi rahatlattığı ifade edilmektedir. Bununla birlikte çiçekleri taze veya kurutulmuş olarak kullanılmaktadır. Bir çay kaşığı çiçek bir bardak kaynamış suda beş dakika demlenir, gargara yapılır. Günde üç kez 
Tablo 2. Çalışılan bitkilerin etnobotanik özellikleri

\begin{tabular}{|c|c|c|c|c|c|c|}
\hline Takson adı & Yöresel Adı & Kullanılan Kısım & Yöre Halkının Uygulama Biçimi & $\begin{array}{l}\text { Yöresel Kullanım } \\
\text { Alanı }\end{array}$ & UV & $\begin{array}{l}\text { Diğer etnobotanik } \\
\text { özellikleri }\end{array}$ \\
\hline \multirow{2}{*}{ E. cicutarium } & \multirow{2}{*}{ Tikencik } & Dal ve yaprak & Pişirilerek tüketilir. & Yiyecek & \multirow{2}{*}{0,039} & \multirow{2}{*}{$\begin{array}{l}\text { Yiyecek, hayvan } \\
\text { yemi }\end{array}$} \\
\hline & & Çiçek & $\begin{array}{l}\text { Bir çay kaşığı çiçek bir bardak kaynamış suda } \\
\text { demlenerek gargara yapılır. }\end{array}$ & Tibbi & & \\
\hline \multirow{2}{*}{ F. officinalis } & \multirow{2}{*}{$\begin{array}{l}\text { Gelin } \\
\text { tırnağ1, } \\
\text { gelin eli }\end{array}$} & \multirow{2}{*}{ Dal ve yaprak } & Pişirilerek tüketilir. & Tibbi & \multirow{2}{*}{0,050} & \multirow{2}{*}{$\begin{array}{l}\text { Yiyecek, hayvan } \\
\text { yemi }\end{array}$} \\
\hline & & & Kurutulmuş dallar ve yapraklar kaynatılarak içilir. & Trbbi & & \\
\hline \multirow{4}{*}{ P. lanceolata } & \multirow{4}{*}{$\begin{array}{l}\text { Bağa otu, } \\
\text { sinir otu, } \\
\text { sivilli ot }\end{array}$} & \multirow{3}{*}{ Yaprak } & Çiğ olarak, ağrıyan bölgeye sarılır. & Trbbi & \multirow{4}{*}{0,042} & \multirow{4}{*}{$\begin{array}{l}\text { Yiyecek, hayvan } \\
\text { yemi }\end{array}$} \\
\hline & & & Çiğ olarak açık yaraya üzerine konulur. & Tibbi & & \\
\hline & & & $\begin{array}{l}\text { Bir tatlı kaşı̆̆ı kuru yaprak demlenerek içilir. Ayrıca } \\
\text { mantar hastalığında haricen sürülür. }\end{array}$ & Trbbi & & \\
\hline & & Dal, yaprak & $\begin{array}{l}\text { Bir tutam kuru yaprak ve dal karışımı, bir tutam mısır } \\
\text { püskülü, kiraz sapı birlikte kaynatılarak içilir. }\end{array}$ & Tibbi & & \\
\hline \multirow{2}{*}{ R. acetosella- } & \multirow{2}{*}{$\begin{array}{l}\text { Kuzukulağı, } \\
\text { ekşimcek }\end{array}$} & \multirow{2}{*}{ Dal ve yaprak } & Çiğ olarak tüketilir. & Tibbi & \multirow{2}{*}{0,102} & \multirow{2}{*}{$\begin{array}{l}\text { Tat ve aroma } \\
\text { verici, yiyecek }\end{array}$} \\
\hline & & & $\begin{array}{l}\text { Bir bardak sıcak suda bir tutam kuru yaprak } \\
\text { demlenerek, içilir. }\end{array}$ & Tibbi & & \\
\hline \multirow{2}{*}{ S. pecten veneris } & \multirow{2}{*}{ Tarak otu } & \multirow{2}{*}{ Dal ve yaprak } & Pişirilerek tüketilir. & Yiyecek & \multirow{2}{*}{0,019} & \multirow{2}{*}{$\begin{array}{lr}\text { Tat ve } & \text { aroma } \\
\text { verici, } & \text { hayvan } \\
\text { yemi } & \end{array}$} \\
\hline & & & Suda haşlanarak ağrı olan bölgeye konulur. & Tibbi & & \\
\hline $\begin{array}{l}\text { S. media subsp. } \\
\text { media }\end{array}$ & $\begin{array}{l}\text { Cüce otu, } \\
\text { serçe otu, } \\
\text { kuşkuş, } \\
\text { kuşdili }\end{array}$ & Çiçek ve yaprak & $\begin{array}{l}\text { İki tatlı kaşı ̆̆ çiçek ve yaprak karışımı, kaynamış } \\
\text { sıcak suda demlenerek, içilir. }\end{array}$ & Tibbi & 0,148 & $\begin{array}{l}\text { Yiyecek, hayvan } \\
\text { yemi (hayvanın } \\
\text { sütünü arttırır.) }\end{array}$ \\
\hline $\begin{array}{l}\text { T. pratensis subsp. } \\
\text { pratensis }\end{array}$ & $\begin{array}{l}\text { Tekel otu, } \\
\text { yemlik }\end{array}$ & Dal, yaprak & Pişirilerek tüketilir. & Yiyecek & 0,143 & Hayvan yemi \\
\hline
\end{tabular}

Tablodaki ifadelerin tümü yöre halkı tarafından söylenmiştir. Modern tıbbın tavsiyeleri değildir. 
kullanıldığında ağız yaralarını iyileştirdiği yöre halkı tarafindan bildirilmektedir. Bitki bütün olarak hayvan yemi olarak da kullanılmaktadır. Hayvanlarda süt arttırdığ düşünülmektedir. Erodium cicutarium taksonunun UV değeri 0.039'dur (Tablo 2). Fumaria officinalis taksonu yöre halkı tarafından "gelin tırnağı, gelin eli "gibi isimlerle bilinmektedir. Yine çiçeklenmeden önceki dönemde türün dal ve yaprakları zeytinyağı ve bulgurla pişirilerek yenilir. $\mathrm{Bu}$ şekilde tüketildiğinde hazmı kolaylaştırdığ 1 , idrar söktürdüğü ifade edilmektedir. Haftada iki üç defa tekrarlanmalıdır. İlk çıktığı zamanlarda yapraklar toplanır ve kurutulur. Bir tatlı kaşığı kadar kuru yaprak bir su bardağı kadar suda haşlanır ve suyu içilir. Çiçeklendikten sonra ise hayvan yemi olarak kullanılır. Fumaria officinalis taksonunun UV değeri 0.050'dir (Tablo 2).

Tokat ve çevresinde Plantago lanceolata "bağa otu, sinir otu, sivilli ot” olarak bilinmektedir. Türün ilk çıkan yaprakları "pancar kavurması" isimli yemeğe katılmaktadır. Burkulan veya vücutta ağrı olan herhangi bölgeye üç dört yaprak çiğ olarak sarılır. Bu şekilde ağrı kesici olarak etki gösterdiği, açık yaralarda da yine aynı yöntemle iyileştirme etkisi olduğu yöre halkı tarafindan söylenmiştir. Yedi sekiz yaprak açık yara üzerine konularak yöresel olarak tedavi yapılır. Kurutulmuş olan yaprak bir tatlı kaşığı kadar kaynamış olan suda demlenir ve içilir. Sabah akşam içildiğinde tansiyonu ve kan şekerini düzenlediği, idrar söktürdüğü, bağırsak iltihaplarını giderdiği, bu şekilde elde edilen suyunun, mantar hastalığının iyileştirilmesinde kullanıldığ1 ifade edilmektedir. Kurutulmuş dal ve yaprak karışımı mısır püskülü ile kaynatılıp bir su bardağı kadar sabah akşam içildiğinde damar tıkanıklığını açtığını yöre halkı belirtmektedir. Plantago lanceolata taksonunun UV değeri 0.042 (Tablo 2).

Rumex acetosella taksonu yörede "kuzukulağı, ekşimcek" olarak adlandırılmaktadır. Genellikle çiğ olarak tüketilir. Özellikle nezle olan kişilerin günde üç kez Rumex acetosella yapraklarını tüketmesi gerektiği halk tarafindan söylenmektedir. Yine yapraklar sabah ve akşam yenildiğinde prostat büyümesini tedavi ettiği, tansiyonu ve kan şekerini düzenlediği düşünülmektedir. Dallar ve yapraklar kurutulup bir tatlı kaşığı kadar kaynatılmış suda demlenip, sabah akşam içildiğinde böbrek taşını düşürdüğü söylenmektedir. Bu bitki yörede özellikle salatalarda tüketilmekte ya da tat ve aroma verici olarak değerlendirilmektedir. Rumex acetosella türünün UV değeri ise 0.102 'dir (Tablo 2).

Scandix pecten-veneris yörede "tarak otu" olarak bilinmektedir. Kullanılan kısımları çiçeklenmeden önce ilk çıkan yapraklar ve dallardır. Dallar ve yapraklar yağda kavrulup yendiğinde karın ağrısını geçirdiği, hazımsızlığa iyi geldiği ifade edilmektedir. Yine dallar ve yapraklar az bir suda hafifçe haşlanır. Vücudun herhangi bir yerinde ağrı olduğu zaman ağriyan bölgeye 1lık konulup bekletildiğinde ağrı kesici özellik gösterdiği belirtilmektedir. İlk çıkan yaprakları salatalara tat ve aroma verici olarak da kullanılmaktadır. Türün UV değeri 0.019'dur (Tablo 2).
Stellaria media subsp. media taksonu yörede ise "Cüce otu, serçe otu, kuşkuş, kuşdili” gibi isimlerle bilinmektedir. İlk çıkan yapraklar ve dallar toplanıp "pancar kavurması" adı verilen yemeğin içine katılır. Bulgurla zeytinyağı ile kavrularak yenilir. Çiçeklendikten sonra kurutulmuş olarak veya taze çiçekleri kullanılmaktadır. İki tatlı kaşı̆̆ı çiçek yaprak karışımı kaynamış sıcak suda demlenir ve içilir. Günde üç dört kez kullanıldığında hemoroidi iyileştirdiği. Ve aynı şekilde kullanıldığında mide kanamalarına da iyi geldiği yöre halkı tarafindan bildirilmektedir. Ayrıca hayvanlarda süt arttırmak amaciyla yem olarak da kullanılmaktadır. Stellaria media subsp. media taksonunun UV değeri 0.148'dir (Tablo 2).

Tragopogon pratensis subsp. pratensis yörede "tekel otu, yemlik" olarak bilinen bitki "pancar kavurması" denilen yemeğe katılır. Yine diğer türlerde olduğu gibi çiçeklenmeden önceki dönemde ilk çıkan yapraklar ve dallar zeytinyağı ile pişirilir. Haftada bir iki kez yenildiğinde sindirim sistemi düzenlediği ve mideyi rahatlattığı yöre halkı tarafından ifade edilmektedir. Yine diğer türlerde olduğu gibi çiçeklenmeye doğru hayvan yemi olarak kullanılmaktadır. Tragopogon pratensis subsp pratensis taksonunun UV 0.143'tür (Tablo 2).

\section{DEĞERLENDİRME VE SONUÇ}

Etnobotanik açıdan Tokat ve çevresindeki, araştırma konumuzu oluşturan bitkiler detaylı bir şekilde incelenmiştir. Yüz yüze veya anketler aracılığıyla 297 kişi ile görüşülmüştür. $\mathrm{Bu}$ kişilerin \%73'ü kadın, \% 82'si evli, \%43'ü ilkokul mezunu, \%63'ü köyde ikamet etmekte ve \%60'ı ev hanımıdır. Yörede bitkilerden \%89 oranında tıbbi, \%69 oranında ise yiyecek amaçlı yararlanıldığ1 tespit edilmiştir. Katılımcıların \%17.5'i Erodium cicutarium'u, . \%18.9'u Fumaria officinalis'i, \%44.7'si Plantago lanceolata, \%13.5'i Scandix pecten veneris'i, \%64.6's1 Stellaria media subsp. media'y1, \%62'si ise Tragopogon pratensis subsp pratensis'i kullanmaktadır.

Araştırma konusu olan bu bitkilerin bazıları ülkemizin farklı bölgelerinde de kullanılmaktadır. Örneğin; Scandix pectenveneris Alaşehir'de (Manisa) solunum yolları rahatsızlıklarında kullanılmaktadır [41]. Plantago lanceolata Uşak ve çevresinde sinirli ot olarak bilinmekte, ağız ve üst solunum yolları enfeksiyonlarında gargara şeklinde göz iltihaplarında damla yaraların iyileştirilmesinde ise lapa şeklinde kullanılmaktadır [7]. Benzer uygulama Pakistan'da da yapılmaktadır. Yağda yapılan macun eklemlere uygulandığında ağrıyı kestiği ifade edilmektedir [42]. Plantago lanceolata'nın çiğ şekilde ağrı kesici olarak kullanılması bizim çalışmamızda ileri sürülmüştür. Yine mantar hastalığında kullanılması ile ilgili de literatürde herhangi bir çalışmaya rastlanılmamıştır. Pakistan'da hardal yağında pişirilerek eklem ağrısı tedavisi için kullanılmaktadır [42]. Rumex acetosella ise Uşak ve çevresinde "Eşki kulak" olarak bilinmektedir. İştah açıcı ve kan temizleyici olduğu düşünülerek tüketilmektedir [7]. Deniz ve ark. [7] Baytop [9] Şimşek ve ark. [43] "ekşimcek, 
ekşikulak, ekimenek, tırşak" adları ile $R$. acetosella'nın bilindiğini, bitkinin ekşi yapraklarının salatalarda kullanıldığını belirtmişlerdir. Köklerinin ise idrar arttırıcı, safra söktürücü ve ateş düşürücü etkilerinin olduğu düşünülmektedir [9]. Bu kullanım Tokat yöresinde kullanımı ile paralellik göstermektedir. $R$. acetosella Ergan Dağı ve çevresinde (Erzincan) kuzukulağ Tokat'taki kullanımına benzer şekilde, yaprakları çiğ olarak yenilmekte veya salatalarda kullanılmaktadır. Bağırsak çalıştırma özelliği de bulunmaktadır [44]. R. acetosella kurtulmuş yapraklarının demlenip içildiğinde böbrek taşı düşürdüğü ilk defa çalışmamızla ifade edilmiştir. Tragopogon buphtalmoides var. buphthalmoides türü de Ergan Dağı ve çevresinde, (Erzincan) tıpkı T. pratensis subsp pratensis gibi yemlik olarak adlandırılmakta ve gida olarak tüketilmektedir [44] Erodium cicutarium'un ağız yaralarını iyileştirdiği çalışmamızda ifade edilmiş, daha önce bu konu ile ilgili bir çalışmaya rastlanılmamıştır. Lis-Blchin [45] Erodium ciccutarium'un çiçeklenmeden önceki dönemde toplanan yapraklarının uçucu yağ bakımından zengin olduğunu ortaya koymuştur. Radulovic ve ark. [46] Erodium cicutarium'un yaprak ve gövdesinde bulunan uçucu yağları araştırmışlar ve bitkinin yüksek oranda yağ asidi içerdiğini tespit etmişlerdir. Ayrıca Radic ve ark [47] bulunan bu uçucu yağların yüksek antibakteriyel etki gösterdiklerini belirtmişlerdir. Erodium cicutarium subsp. cicutarium'un kabızlık için kullanıldığı Çakılcıŏglu ve Türkoğlu [48] tarafindan belirtilmiştir. Demirci ve Özhatay tarafindan [49] Kahramanmaraş'ta Fumaria officinalis'in şahtere olarak bilindiği, pişirilerek yenildiğinde kan şekerini düşürdüğü bildirilmektedir. Özenç [50] taksonun fenolik ve flavonoid maddelerce zengin olduğunu, doğal bir antioksidan özellik gösterdiğini ve elde edilen sonuçların "tıp, farmasötik ve gida sanayinde potansiyel antioksidan olarak kullanılabilirliği” olduğunu söylemektedir. Tirtash ve ark. [51] Fumaria türlerinin halk arasında sindirim sistemi düzenleyici, cilt rahatsızlıklarını giderici etkisi olduğunu ifade etmektedir Çalışmamızda kullanım değerlerine (UV) baktığımız zaman yöre halkı tarafindan en çok başvurulan türün Stellaria media subsp. media (0.148) olduğu görülmektedir. Sargın ve ark. [41] yaptıkları bir çalışmada Stellaria media UV değerini 0.11 olarak belirlemişlerdir. İkinci sırada ise Tragopogon pratensis (0.143) yer almaktadır. Tragopogon pratensis subsp pratensis ile ilgili etnobotanik bulgular ve UV değeri ilk defa çalışmamızda ortaya konulmuştur. En düşük kullanım oranı ise Scandix pecten-veneris (0.019) aittir. Çalışma konumuzu oluşturan türlerin yaprak, dal, çiçek, otsu gövde gibi kısımlarından faydalanılmaktadır. Daha çok demleme şeklinde metot kullanıldığ 1 görülmüştür. Çakılcıŏlu ve Türkoğlu[52] Sivrice (Elazı̆ğ)'de yaptıkları bir çalışmada demlemenin metodunun çok kullanıldığını ortaya koymuşlardır.

Türlerin ekonomik ve tıbbi bakımdan değer taşıması nedeni ile çalışmamızın sonuçları, hem bilimsel, hem de uygulamaya dönük olarak önemli bulgular ortaya koymaktadır. Araştırmamıza konu olan bu taksonların Tokat'ta kullanımı oldukça yaygındır. $\mathrm{Bu}$ bağlamda geleneksel tedavide yöre halkı tarafindan kullanılan türlerin toplumsal sağlığın korunmasında önemli olacağını düşünmekteyiz. Bu çalışma, bu alanda bir başlangıç olup; söz konusu bitkilerin tıbbi ve farmakolojik özellikleri üzerinde daha detaylı çalışmalar yapılması gerektirmektedir.

\section{KAYNAKÇA}

[1]. H. Birand, "Türkiye Bitkileri”, Ankara Üniversitesi Fen Fakültesi Yayınları Um.58, Botanik. 1, Ankara, 1952.

[2]. M. Avc1, "Türkiye'nin Flora Bölgeleri ve Anadolu Diyagonaline Coğrafi Bir Yaklaşım", Türk Coğrafya Dergisi 28. 225-248, 1993.

[3]. A. Güner, S. Aslan, T. Ekim, M. Vural ve M. T. Babaç, "Türkiye Bitkileri Listesi (Damarlı Bitkiler)", Nezahat Gökyiğit Botanik Bahçesi ve Flora Araştırmaları Derneği Yayını, 2012.

[4]. G. Eken ve M. Ataol, "Türkiye'nin Biyocoğrafyası. Türkiye'nin Önemli Doğa Alanları”, Cilt 1 sayfa 24-28. Türkiye'nin Önemli Doğa Alanları Derneği Ankara. Baskı: Mas Matbaacıllk, İstanbul, 2006.

[5]. G. Kendir ve A. Güvenç, "Etnobotanik ve Türkiye'de Yapılmış Etnobotanik Çalışmalara Genel Bir Bakış", Hacettepe Üniversitesi Eczacilık Fakültesi Dergisi, Cilt 30, Say1 1 ss. 49-80, 2010.

[6]. E. Tuzlaci and E. Tolon "Turkish folk medicinal plants, Part III: Şile (İstanbul)", Fitoterapia; 71: 673-685, 2000.

[7]. L. Deniz, A. Serteser ve M. Kargığlu, "Uşak Üniversitesi ve Yakın Çevresindeki Bazı Bitkilerin Mahalli Adları ve Etnobotanik Özellikleri”, AKÜ Fen Bilimleri Dergisi, 1 57-72, 2010.

[8]. S. Diksha and B. Amla, "Ethnobotany and etnopharmacology-past, present and future", International Journal of Pharmaceutical Innovations, 1,86-92, 2011

[9]. T. Baytop, Therapy with Medicinal Plants in Turkey (Past and Present). Istanbul University Publications, İstanbul, 1999.

[10]. T. Tütenocaklı, “Ayvacık (B1, Çanakkale) ve Çevresinin Etnobotaniği”, Çanakkale Onsekiz Mart Üniversitesi, Fen Bilimleri Enstitüsü, Yüksek Lisans Tezi, Çanakkale, 2002.

[11]. M. Heinrich, J. Barnes, S. Gibbons and E.M. Williamson, "Fundementals of Pharmacognosy and Phytotherapy", Churchill Livingstone, Edinburgh, 2004.

[12]. Ş. Yıldırım, "Etnobotanik ve Türk Etnobotaniği" Kebikeç. İnsan Bilimleri İçin Kaynak Araştırmaları Dergisi, Y1l: 9 Say1: 17. Sayfa 175-194, 2004.

[13]. E. Sezik, M. Tabata, E. Yeşilada, G. Honda, K. Goto and Y. Ikeshiro, "Traditional medicine in Turkey I Folk medicine in North-East Anatolia", Journal of Ethnopharmacology, 35, 191-196, 1991.

[14]. E. Sezik, E. Yeşilada, M. Tabata, G. Honda, Y. Takaishi, F. Tetsuro, T. Tanaka and Y. Takeda, "Traditional Folk Medicine in Turkey", VIII. Folk Medicine in East Anatolia; Erzurum, Erzincan, Ağrı, Kars, Iğdır Provinces, Economic Botany, 51: 195-211, 1997.

[15]. F. Ertuğ, "An ethnobotanical study in Central Anatolia (Turkey)”, Economic Botany, 54: 155-182, 2000. 
[16]. E. Tuzlacı and E. P. Aymaz, "Turkish folk medicinal plants, Part IV: Gönen (Balıkesir)”, Fitoterapia; 72: 323-343, 2001.

[17]. F. Özgökçe and H. Özçelik, "Ethnobotanical Aspects of Some Taxa in East Anatolia (Turkey)", Economic Botany, 58 (4): 697-704, 2004.

[18]. F. Güneş and N. Özhatay, "An ethnobotanical study from Kars (Eastern) Turkey", Biological Diversity and Conservation, 4: 30-41, 2011.

[19]. R. Polat and F. Sat1l, "An ethnobotanical survey of medicinal plants in Edremit Gulf (Balıkesir-Turkey)", Journal of Ethnopharmacology, 139: 626-641, 2012.

[20]. M. Korkmaz, "Kelkit (Gümüşhane) Aktarlarında Satılan Tıbbi Bitkilerin Etnobotanik Özellikleri", Cilt 18, Sayı 3, 2014.

[21]. Y. Z. Kocabaş, N. Çömlekçioğlu ve A. İlçim, "Bazı Odunsu Bitki Türlerinin Kahramanmaraş İl Merkezi Ölçeğinde Etnobotanik Yönleri”, Gaziosmanpaşa Bilimsel Araştırma Dergisi Sayı: 12, Sayfa: 60-69, 2016.

[22]. E. B. Yeşilyurt, I. Şimşek, G. Akaydın and E. Yeşilada, "An ethnobotanical survey in selected districts of the Black Sea region (Turkey)", Turk J Bot 41: 47-62, 2017.

[23]. G. Bulut, Z. Haznedaroğlu, A. Doğan, H. Koyu and E. Tuzlaci, An ethnobotanical study of medicinal plants in Acipayam (Denizli-Turkey), Journal of Herbal Medicine, Volume 10, Pages 64-81, 2017.

[24]. P.H. Davis, "Flora of Turkey and the East Aegean Islands", Edinburg University Press. vol I, sayfa 15,88-246, 1965.

[25]. P.H. Davis, "Flora of Turkey and the East Aegean Islands", Edinburgh University Press. vol II, sayfa 15,88246, 1966.

[26]. P.H. Davis, Flora of Turkey and the East Aegean Islands, Edinburgh University Press. vol. V1I-page 15-216265-450- 513, 1967.

[27]. P.H. Davis, "Distribution Patterns in Anatolia with Particular Reference to Endemisim" Plant Life of South West Asia (Ed. P.H. Davis, P.C. Harper, I.C. Hedge) Published by The Botanical Society of Edinburgh p.p 15-28, 1971.

[28]. P.H. Davis, "Flora of Turkey and the East Aegean Islands", Edinburgh University Press. vol. IV-page 1. 1972. [29]. P.H. Davis, "Flora of Turkey and the East Aegean Islands", Edinburgh University Press. vol. V-page 15-216265-450- 513, 1975.

[30]. P.H. Davis, Flora of Turkey and the East Aegean Islands, Edinburgh University Press. vol. V1I-page 505-513, 1982.

[31]. P.H. Davis, R.R. Mill and K. Tan, (Eds.) "Flora of Turkey and the East Aegean Islands", Vol. 10. Edinburgh University Press, Edinburgh, 1988.

[32]. K.N. Denzin, "The Research Act: A Theoretical Introduction to Sociological Methods (3rd edit.)", New Jersey: Prentice-Hall, Inc. 1989.

[33]. R. Trotter and M. Logan, "Informant consensus: a new approach for identifying potentially effective medicinal plants, In plants in indigenous Medicine and Diet: Biobehavioural Approaches, ed. Nina L. Etkin", Redgrave publishers, Bedford Hills, NY. pp.91-112, 1986.
[34]. Ş. Büyüköztürk, "Sosyal Bilimler İçin Veri Analizi El Kitabı”, Pegem Akademi Yayınları, Ankara, 2016.

[35]. J. Pallant, "SPSS Survival Manual, A Step by Steps Guide to Data Analysis", Open University Press, Berkshire, England, 2007.

[36]. S. Akerreta, R.Y. Cavero and M.I. Calvo, "First comprehensive contribution to medical ethnobotany of Western Pyrenees", Journal of Ethnobiology and Ethnomedicine, 3, 26, 2007.

[37]. F.U. Afifi, and B. Abu-Irmaileh, "Herbal medicine in Jordan with emphasis on less commonly used medicinal herbs", Journal of Ethnopharmacology, 72, 101-110, 2000.

[38]. G. Kloutusos, D.G. Balatsouras, A.C. Kaberos, D. Kandiloros, E. Ferekidis and C. "Economou, Upper airway edema resulting from use of Ecballium elaterium", The Laryngoscope 111, 1652-1655, 2001.

[39]. B.E. Abu-Irmaileh and F.U. Afifi, "Herbal medicine in Jordan with special emphasis on commonly used herbs", Journal of Ethnopharmacology, 89, 193-197, 2003.

[40]. T. Teklehaymanot and M. Giday, "Ethnobotanical study of medicinal plants used by people in Zegie Peninsula, northwestern Ethiopia", Journal of Ethnobiology and Ethnomedicine 3, 12, 2007.

[41]. S.A. Sargın, E. Akçicek and S. Selvi, An ethnobotanical study of medicinal plants used by the local people of Alaşehir (Manisa) in Turkey. Journal of Ethnopharmacology 150. 860-874, 2013.

[42]. M. Ajaib, S.K. Haider, A. Zikrea and M.F. Siddiqui, Ethnobotanical Studies of Herbs of Agra Valley, Parachinar, Upper Kurram Agency, Pakistan, Int. J. Biol. Biotec, 11 (1): 71-83, 2014.

[43]. I. Şimsek, F. Aytekin, E. Yeşilada, and S. Yıldırımlı, "An ethnobotanical survey of the Beypazarı, Ayaş, and Güdül District towns of Ankara Province (Turkey)", Econ Bot 58: 705-720, 2004.

[44]. M. Korkmaz ve Z. Alpaslan, "Ergan Dağı'nın (Erzincan-Türkiye) etnobotanik özellikleri”, Bağbahçe Bilim Dergisi, 1 (3) : 1-31, 2014.

[45]. M. Lis-Balchin, "The Essential Oils of Pelargonium grossularioides and Erodium cicutarium (Geraniaceae)", J. Essent. Oil Res, 5, 317-318, 1993.

[46]. N. Radulovic, M. Dekić, Z.S. Radić and R. Palić, "Volatile constituents of Erodium cicutarium (L.) L' Hérit. (Geraniaceae) Cent. Eur”, J. Biol. 4(3), 404-410, 2009.

[47]. Z.S. Radić, L. Čomić, N. Radulović, M. Dekić, V. Ranđelović and O. Stefanović, "Chemical composition and antimicrobial activity of Erodium species: E. ciconium L. E. cicutarium L. and E. absinthoides Willd. (Geraniaceae)", Chemical Papers- Slovak Academy of Sciences 64(3):368377, 2010.

[48]. U. Çakılcığlu, S. Khatun, İ. Türkoğlu ve Ş. Hayta, "Ethnopharmacological surveyof medicinal plants in Maden (Elazığ-Turkey)", Journal of Ethnopharmacology, 137: 469486, 2011.

[49]. S. Demirci and N. Özhatay, "An ethnobotanical study in Kahramanmaraş (Turkey;Wild plants used for medical purpose in Andırın, Kahramanmaraş”, Turk J. Pharm. Sci. 9 (81), 75-92, 2012. 
[50]. B. Özenç, "Fumaria officinalis'in Antioksidan Aktivitesinin Belirlenmesi”, Selçuk Üniversitesi Fen Bilimleri Enstitüsü, Konya, 2011.

[51]. F.H.M. Tirtash, M. Keshavarzi and F. Fazeli, "Antioxidant Components of Fumaria Species (Papaveraceae)", International Journal of Biological,
Biomolecular, Agricultural, Food and Biotechnological Engineering Vol:5, No:2, 2011.

[52]. U. Çakılcıŏ̆lu and İ. Türkoğlu, "An ethnobotanical survey of medicinal plants in Sivrice (Elazığg)", Journal of Ethnopharmacology 132, 165-175, 2010. 